\title{
Attributive Pronouns in the Even language
}

\author{
Valeria S. Fedorenkova* \\ The Herzen State Pedagogical University of Russia \\ 48 Nab. Reki Moiki, St. Petersburg, 191186, Russia
}

Received 19.06.2016, received in revised form 24.07.2016, accepted 02.09.2016

\begin{abstract}
The article discusses the problem of the status of attributive pronouns in the grammatical system of the Even language and analyses their semantic and functional features. The determination of the place of pronouns in the parts of speech system and the issue of their singling out as a separate part of speech remains controversial. Attributive pronouns include consolidative and distinguished words with dissimilar semantics: the qualifiers of the subject and object of the action, consolidation and differentiation, totality and completeness, which are categorically correlative with adjectives, nouns and adverbs. The author shows the lexical and semantic differences of attributive pronouns in the dialects of the Even language, indicates the forms of attributive and attributive-possessive pronouns in the Western dialects that are absent in the Eastern dialects of the Even language.
\end{abstract}

Keywords: Even language, morphology, semantic level of pronouns, attributive pronouns, pronominal words.

DOI: 10.17516/1997-1370-2016-9-10-2406-2412.

Research area: the languages of the peoples of the Russia.

The problem of pronouns is one of the most difficult problems of modern linguistics. Their status pronominalis, place in the parts of speech system, the question of their singling out in a separate part of speech remains debatable. The traditional view on the pronoun as a special part of speech is challenged by many linguists. The discord arises from the different understanding of semantics of pronominatives and their grammatical functions. According to Iu. L. Vorotnikov, "pronouns in the language are a special and, if anything, one of the most enigmatic class of words around which lively linguistic debate evolves, but to this day, many questions of their semantics and functioning in the statement remain controversial" (Vorotnikov, 2001, 42). As a rule, the pronoun is defined as the part of speech indicating objects, features and amounts, without naming them (ngi - "who", he - "you", erek - "this", ady "vul" / ady-gul - "a few"). Many researchers of Russian grammar (A.M. Peshkovskii, N. Iu. Shvedova, E.N. Sidorenko, O.E. Rudenko et al.) consider this definition not enough complete and tend to treat the pronoun as a special part of speech, categorically related to nouns, adjectives, numerals, adverbs, impersonal-predicative words, which "having a

(C) Siberian Federal University. All rights reserved

* Corresponding author E-mail address: valeria.141169@mail.ru 
special pronominal method of objective reality representation" (Sidorenko, 2005, p. 31).

Based on the main lexical and semantic functions of pronominatives and their grammatical function in the Even language, we can distinguish the following types:

1) pronouns, correlative with nouns: bi - "I", hi - "you", ngi - "who", iak - "what", ngi-de "nobody", ngi-vul - "someone", chelen - "all", "iak-ta" - "nothing", erek - "this", etc.;

2) pronouns, categorically correlative with adjectives: irek - "which", irek - "what", errochin / erbochon - "such, like", tarrochin / tarbochon - "such", erek-kul - "some, certain", irek-kul - "a kind of, some", tarak - "that one", erek - "this", irek-te - "no one, every", irektarak - "anyone, anyone else, another", and so on;

3) pronouns, categorically correlative with numerals: adi - "how many, how much", tardin "so many", ady-vul (ady-gul) - "any, some";

4) pronouns, correlative with adverbs: ile - "where", irteki / irtiki - "where to", iduk - "where from", on - "how", ok - "when", iami - "why", ahun -"for how many, far", tala "there", ele - "here", erteki / ertiki - "to here", taduk - "from there", iami-vul / iami-gul - "for some reason", hadun - "sometimes", ereger "always", and so on.

Semantic classification of pronouns, which the compilers of textbooks adhere to, includes the following types:

1. personal: bi -“I”, hi - "you sg.", nongan "he", mut (inclusive form), bu (exclusive form) “we”, hu - "you pl.", nongartan - they.

2. reflexive: meeni (sg.), meenur, meerbur (pl.) "self"; and reciprocal: meen meenur / meer meerbur - "each other".

3. personal-possessive in the short and long forms: $\min$ (bi in the lamun. dialect), minngi - "my", hin (he in the lamun. dialect), hinngi - "your, someone's, his, her, their, our, your", which are formed from the stems of personal and reflexive pronouns by adding the affix -ngi. Unlike the literary language possessive pronouns in some dialects, such as Lamunhinskii, are formed from stems of attributive pronouns bey- and meen-. Thus, in this dialect there are three groups of possessive pronouns: personal-possessive, reflexivepossessive, attributive- possessive.

In contrast to the sub-dialects of the eastern dialects, non-independent forms of personalpossessive pronouns 1 p., 2 p. sg. and pl. are not used in Lamunhinskii dialect. These pronouns include min - "my", hin - "your", mun - "our" (inclusive), bun - "your" (exclusive) and many others. Independent forms are based on these stems with adding the affix -ngi (except mun-): minngi, hinngi, hunngi. Personal-possessive pronoun $1 \mathrm{p}$. pl. is formed from the stem of mut: mutngi - "our"; 3 p. sg. and pl. are formed from the stem nong-: nongngin - "his", lit. nongarngitan, lam. - nonngitnan, in the okhot. dialekt - nongngitan meaning "their". Possessive forms in the Even language form other pronouns types by adding the possessive suffix -ngi: erngi - "belonging to this", erel-ngi - "belonging to these", etc.

4. Demonstrative: tar - "this one", tarak "that one", tavara - "yonder", er - "this very", erek - "this", errochin / erbochon - "such as this", tarrochin / tarbochon - "such as that one", tardin - "how many, much", tala - "there", ele - "here", tartaki - "there", erteki - "to here", taduk - "from there", eduk - "from here", tachin - "so", tarakam - "then", tarit - "after", tiemi - "because, so", tachikan - "insomuch".

5. Interrogative: ngii - "who" (about a person), iak - "who, what", irrochin / irbochon "what", niingi - "whose", irek - "which", avug "which one", adi - "how many, much", ahun "which" (in size, volume, etc.), "to what extent", ile - "where", irteki - "to where", iduk - "from 
where", on - "how", ok - "when", iami - "for what reason, why".

6 . Interrogative pronouns by adding particle -da become negative in sentences with a negative predicate: ngi-de achcha - "there is no one".

7. Indefinite pronouns are formed by adding particles -ul / -vul / -gul, -da / -de to the interrogative pronouns.

8. Attributive pronouns, which are the subject of this article.

Pronominal words, which are traditionally called attributive, do not have common semantic content. They are categorical correlative with different parts of speech and perform the corresponding functions. On the basis of this, some linguists (A.M. Peshkovskii, E.N. Sidorenko, O.E. Rudenko, E.V. Paducheva) offer to call them generalizing, or generalizingexclusive pronouns.

Attributive pronouns in the Even language, as well as in Russian, "provide a means of clarifying the object in question, they give it a value or generalize it" (Russian grammar corpora, http://rusgram.ru). Theirmainsemantic feature is the ability to specify, based on the already mentioned or known facts. In this case there is necessarily an element of comparison, a comparison and contrast. By virtue of their ability to indicate through already said or known, attributive pronouns are often used as anaphors, while generalizing pronominal words perform a quantifying function. Attributive pronominal words, categorically correlative with names, tend to decline, but not all pronouns have a full paradigm of declension, including possessive forms. In addition, they form plurals and possessives. In sentences these pronouns are subjects, objects, attributes, different adverbials. Pronouns eeidu, meenken do not decline.

In the Even language the attributive pronouns include:
1) Pronouns with universal-quantifying meaning: 1) pointing to the entire set, "meaning aggregate, generalization and complete coverage of anything" (Lebedev, 1982, p. 66): eeidu "whole, all", bekech - "completely, full", bekechen - "all", bekechchur - "everyone", cheele, cheelen - "all, the whole, entire, every", kubechen - "every, all, whole", kubechchur "everybody", butun / butunni - "whole, full". 2) Pronouns, pointing to an arbitrary object in the set: kubech, giaki, giakitang - "anyone, anybody, anything, different", beiteen - "each person”, irek-tarak - “any, every”. In the Okhotsk dialect V.D. Lebedev discovered the pronominal words chiistan - "all", borrowed from the Russian language: "Chiistan okooskal avatlal" (All windows have been washed) (Lebedev , 1982, p .66). Pronouns with exclusive meaning are also formed from the interrogative pronouns: ngii - "who", iak - "what", irek - "which" by adding the definitive particle -ta / -te , -da / -de , -tta / -tte: irek te - "no one, everyone", ngi-de "anyone, anybody", iak-ta - "anything, either".

2) Amplifying and exclusive words derived from different stems and semantically heterogeneous. Derived from reflexive pronoun meen- words meenken - "by oneself, alone" meerker - "by themselves, alone" are used for the accentuation of an active person and have the meaning of "self-sufficiency" (bi meenken ele emrem - "I came here myself" - without crutches) and "significant personal involvement" (nongan meenken ele emren - "He came here" instead of sending someone). The described category also includes: beiu - "myself" (in Lamunhinskii dialect it has a complete paradigm of declination), beid'i - "self", beiteen - "each" (person), tarak - "that one", erek - "this one", erdin - "the same as this one (in size, volume, and so on), haan - "some, partial", adykun / adukun - "little, a small amount", abal - "little", hooia - "many, much". The pronoun beiteen - 
"every" (person) is used without main noun, as its semantics bears the meaning of a person (bei): Tavar ngin beiteendu eten horre (That one dog will not go to everybody).

In Lamunhinskii dialect of the western dialect of the Even language there are other than those listed attributive pronouns, which have no analogues both in the literary language and in the eastern dialects. It is interesting that the Evenk language has the same pronouns. These attributive

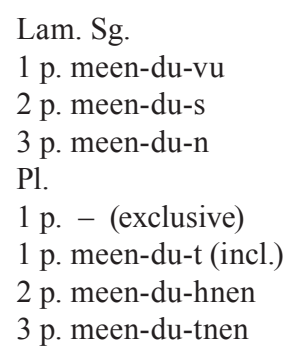

In the western dialects such definitive pronouns are formed from the synonymous stem bei-/boi-. In contrast to pronouns, formed from the stem of the reflexive pronoun meen-, pronominatives, formed on this stem (bei-/ boi-), have a complete paradigm of declension with personal-possessive affix. Attributive pronoun with the stem bei-/boi- (self) is found not only in Lamunhinskii dialect, but also in the Okhotsk dialect. The presence of similar attributive pronouns in these two dialects is a proof of their proximity. V.D. Lebedev in his work "The Okhotsk Dialect of the Even language" indicates the genetic relationship of the stems bei- and meen- and gives examples of the bei- usage with the meaning of attributive

$$
\begin{aligned}
& \text { Even } \\
& 1 \text { p. bei-u } \\
& 2 \text { p. bei-es } \\
& 3 \text { p. bei-en }
\end{aligned}
$$

In the Midwestern dialects pronoun bei- may be used in conjunction with personal pronouns, dependent on them in number, case and person. In pronouns are formed from the stem meen(reflexive pronoun) by adding dative and locative case affixes and personal-possessive affixes. Their meaning is close to the reflexive pronouns in dative and locative cases: meendi, meendulei, meendur / meenduvur / meendulevur. While reflexive pronouns are impersonal, attributive pronouns indicate the person. In addition, in sentence they refer not only to the subject, but also to indirect object in dative case:
to myself to yourself to himself
to ourselves to ourselves to yourselves to themselves

pronoun in indirect cases: "On the basis of the data of all Tungus languages I assume that the stem of reflexive and attributive pronouns meen- (self) is a phonetic modification of the older stem *beien. In this alleged form $\mathbf{i}$ dropped, two vowels contracted in long e, anlaut $b$ was modified and became $\mathbf{m}$ under the influence of the subsequent $\mathbf{n}$, i.e. beien *> * been $>$ * meen (Lebedev, 1982, p. 67). "It is interesting to note that in the Manchu language words bei "self" or beise "themselves" are used as reflexive pronouns" (Lebedev, 1978, p. 78). The stem bei- or beien is common for the Altai languages. For example, the Yakut language (the Turkic group) has attributive pronouns formed from the stem bei-, cf.:

Yakut

bei-em myself

bei-eng yourself

bei-ete himself

Lamunhinskii dialect this dependence is optional, as this dialect has lost harmonization of attributive word-combinations (Fedorenkova, 2010, p. 104). 
Sg.

1 p. bi beiu / boiu

2 p. he beies / boi-os

3 p. nongan bei-en /boi-on
Pl.

mut beiet/boiot

ourselves

hu beiesen/boiohnon

yourselves

nongartan beietnen/boiotnon themselves
These pronouns decline as possessive stems ending with a consonant. It should be noted that the meaning of the pronoun bei / boi "self" in the dative case coincides with the meaning of the pronoun derived from the stem meen-. The latter does not have a complete paradigm of declension, for example:

1 p. beidu-vu/ meendu-vu to myself, 2 p. beidu-s/ meendu-s to yourself, 3 p. beidu-n/ meendu-n to himself.

In some Even dialects in Yakutia (in DogdoChebogalahskii, Momskii, Lamunhinkii) and in the Okhotsk dialect there are attributivepossessive pronoun similar to the Evenk ones.

\section{Sg. Lam., \\ 1 p. meen-ngi-v(u) \\ 2 p. meen-ngi-s \\ 3 p. meen-ngi-n \\ Pl. Lam.}

1 p. -

1 p. meen-ngi-t

2 p. meen-ngi-hnon

3 p. meen-ngi-tnon
Okhotsk men-ngi-v men-ngi-s men-ngi-n Okhotsk meen-ngi-vun

meen-ngi-t meen-ngi-sni/ meen-ngi-sen meen-ngi-tni meen-ngi-ten
Forms of attributive-possessive pronouns are derived from the reflexive stem meen- by adding the affix -ngi followed by the personal affix, for instance:

\section{Evenk}

my own

your own

his own

Evenk

men-ngivun/ our own mer-ngi-vun

men-ngi-t / our own

mer-ngi-t

men-ngi-sun/ your own

mer-ngi-sun

men-ngi-tyn / their own

mer-ngi-tyn

But in contrast to the Okhotsk dialect and the Evenk language, in the Lamunhinskii dialect not only from the stem meen-, but also form attributive pronouns with the stem bei-, attributive- possessive pronouns are formed

$\mathrm{Sg}$.

1 p. boi-ngi-vu

2 p. boi-ngi-s

3 p. boi-ngi-n

$\mathrm{Pl}$.

$\begin{array}{lll}\text { my own } & \text { boi-ngi-t } & \text { our own } \\ \text { your own } & \text { boi-ngi-hnon } & \text { your own } \\ \text { his own } & \text { boi-ngi-tnon } & \text { their own }\end{array}$

3) Pronouns, indicating the equivalence of subjects on various parameters: size, length, volume, width, height, etc. These are pronouns, formed from demonstrative pronouns: er - "this one", tar - "that one" by adding affixes -rochin / -rbochon , -dyn / -din: er-rochin / er-bochon "the same as this", tarrochin / tarbochon - "the same as that one", er-din - "the same as that (in size, volume, etc.)", tar-din - "the same as that (in size, volume, etc.). In the Even dialect in Berezovka 
V.A. Robbek finds personal- possessive pronouns erdin, tardin: "Suffix -din forms attributive pronoun pointing to objects of equal size... Attributive pronouns erdin, tardin, apparently, are historically complex, as they consist of words er - "this", tar - "that" and di - "size, volume, height". In attributive pronouns vowel $\mathbf{i}$ is short, and the word di is always used with personalpossessive suffixes (di-n, di-s, di-v) (Robbek, 1989, p. 126). In the Lamunhinskii dialect there remained one form with the possessive $3 \mathrm{p}$. affix -n: erdi-n, tardi-n. In the literary language and Eastern dialects these attributive pronouns have a complete paradigm of simple declension in singular and plural. In the Lamunhinskii dialect substantive pronouns decline only when they are subjects or objects, while being a component of attributive phrases they do not decline, so they are adjacent to the main noun (Fedorenkova 2010, p. 104). Attributive pronouns errochin, tarrochin "were formed by the fusion of the demonstrative pronoun er / tar and the word urechin - "similar": errochin <er + urechin and tarrochin <tar + urechin" (Dutkin, 1995, p. 42).

4) Pronominal words meaning "different": gia - "another, different", hoonte / huunte "another, strange", gaad - "the other, one of the pair", haan - "the other" (about a part, some), angili - "different, different from others".

Semantic and functional heterogeneity of attributive pronominal words complicates the definition of their grammatical status. These words are correlative with nominal parts of speech, adverbs and pronouns. V.D. Lebedev considers attributing some words to the attributive pronouns erroneous: "The closeness of meanings of attributive pronouns to adverbs and names makes us be careful concerning attribution of certain words. When one places attributive pronouns in special category, one must take into account the context. For example, some grammatical works on the Even language enlist mistakenly some nouns among the attributive pronouns in the literary language (haan - "a part of smth, sb"; hooia - "a large amount of smth, a lot"), and also adjectives (gee - "another, second"; hoonte - "another, strange, alien"; abal, adikun - "incomplete, insufficient, little") (Lebedev, 1982, p. 68).

Not only in the Even language pronominal attributive words cause difficulties in classification. The authors of some classifications are moving away from the term "attributive pronouns". A.M. Peshkovskii places these pronouns in three categories: generalizing, aggregate and exclusive (Peshkovskii, 2001, p. 157). V.N. Migirin calls attributive pronouns negatively generalizing and positively generalizing (Migirin, 1973, p. 218). Semantic heterogeneity of attributive pronouns, as they perform different syntactic functions (not only those of adjectives), being subjects, objects or adverbial modifiers, necessitating the change of the term "attributive pronouns". Based on their nature and meaning, E.N. Sidorenko proposes to call them generalizingexclusive (Sidorenko, 2005, p. 45). Yet, difficulties in determining the place of attributive pronominativesin the grammatical system of the Even language, their functional-semantic and dialectal features require further comprehensive research.

\section{References}

Dutkin, Kh.I. (1995). Allaikhovskii govor evenov Iakutii [Allaikhovskiy vernacular of Yakutia Evens]. Saint-Petersburg, 144 p.

Fedorenkova, V.S. (2010). O soglasovanii komponentov atributivnykh konstruktsii v govorakh evenskogo iazyka [On concord of the attributive constructions' components in the Even language dialects], In Voprosy istorii i kul'tury severnykh stran i territorii [Issues of history and culture of the Northernvcountries and territories], 2 (10), 104-112. Syktyvkar. 
Lebedev, V.D. (1978). Iazyk evenov Iakutii [The language of Yakutia Evens]. Leningrad, 208 p.

Lebedev, V.D. (1982). Okhotskii dialect evenskogo iazyka [The Okhotsk dialect of the Even language]. Leningrad, $243 \mathrm{p}$.

Migirin, V.N. (1973). Iazyk kak sistema kategorii otobrazheniia [Language as a system of displaying categories]. Chisinau, $220 \mathrm{p}$.

Peshkovskii, A.M. (2001). Russkii sintaksis v nauchnom osveshchenii [Russian syntax in a scientific light]. Moscow, $510 \mathrm{p}$.

Robbek, V.A. (1989). Iazyk evenov Berezovki [The language of Berezovka Evens]. Leningrad, 206 p.

Rudenko, O.E. (2012). Funktsional'naia nagruzka obobshchaiushche-vydelitel'nykh mestoimenii v predlozhenii [Functional load of generalizing-exclusive pronouns in a sentence], In Kul'tura narodov Prichernomor'ia [Culture of the Black Sea region], 224, 189-191.

Russian Corpore Grammar. Pronoun, available at: http://rusgram.ru.

Sidorenko, E.N. (2005). Teoreticheskie i prakticheskie materialy po morphologii sovremennogo russkogo iazyka: uchebnoe posobie v 5 chastiakh. Ch. 2. Imia prilagatel'noe. Imia chislitel'noe. [The theoretical and practical material on the morphology of modern Russian language: a textbook in 5 parts. P. 2. Adjective. Numeral. Pronoun]. Simferopol, SSU.

Vorotnikov, Iu.L. (2001). Mestoimeniia kak "iazykovye kategorizatory" [Pronouns as "language categorizers], In Filologicheskie nauki [Philological Sciences], 5, 42-49.

\section{Определительные местоимения}

\section{в Эвенском языке}

В.С. Федоренкова

Российский государственный педагогический университет им. А.И. Гериена Россия, 191186, Санкт-Петербург, наб. Мойки, 48

В статье рассматриваются проблемы статуса определительных местоимений в грамматической системе эвенского языка, анализируются их семантические и функииональные особенности. Определение места прономинативов в системе частей речи, вопрос их выделения в особую часть речи остается дискуссионным. К определительным местоимениям относятся обобщительно-выделительные слова с разнородной семантикой: уточнители субъекта и объекта действия, обобщения и выделения, совокупности и полноты охвата чего-либо, категориально соотносительные с именами прилагательными, существительными и наречиями. Автор статьи показывает лексико-семантические различия определительных местоимений в говорах эвенского языка, указывает на наличие в западных говорах форм определительных и определительно-притяжательных местоимений, отсутствующих в восточном наречии эвенского языка.

Ключевые слова: эвенский язык, морфология, семантические разряды местоимений, определительные местоимения, местоименные слова.

Научная спещиальность: 10.02.02 - языки народов Российской Федераџии. 